\title{
特集 II【論説】都市・住宅と防犯
}

\section{防犯環境設計の実際的側面と課題 \\ Practical side and problem of CPTED}

Toshiya YAMAMOTO : Assoc.Prof., Dept of Architecture, Meiji University

山本 俊哉*

Recently, the number of houses where the crime prevention glass and high-tech equipment were set up has increased. Those strategies contains the problem of the cost rise and "fortress mentality". Therefore, if the balance is not noted, there is a possibility that a difference of the crime prevention performance and various obstacles in life are caused. The crime prevention measures of the part that won't be seen from surroundings are insufficient. Moreover, it is set up in the place where the lighting and the security camera are improper.

If CPTED (Crime Prevention Through Environmental Design) is executed from the plan stage, the crime prevention measures to be effective and balanced can be expected. The cost of the crime prevention glass and the high tech gadget can be reduced if it does so. There is a possibility of improving the community empowerment and the amenity if the resident activity is put in.

It is basic that CPTED works inclusively according to the characteristic of the region and the house. The problem in the future is to enhance the support system.

keywords : target hardening access control fortress mentality defensible space 被害対象の強化 接近の制御 要塞の心理 守りやすい住空間

\section{1 はじめに}

最近の犯罪不安感の高まりがモラル・パニック かどうかはともかく, 住宅を購入又は賃貸する際 においても，犯罪予防が大きな関心事になってき ている。例えば，2004年 8〜9 月に富士総合研究 所（現・みずほ情報総研）が実施した調査iによる と, 回答者の 6 割が住宅の防犯について「予算に 余裕があれば考慮する」と答え,「多少予算を超え
たり，他の条件を犠牲にしてでも考慮する」とし た者は1.5割もいた。こうした犯罪予防のニーズを 受け，住宅の防犯環境設計の取り組みが加速度的 に進んでいる。

防犯環境設計 (CPTED:Crime Prevention Through Environmental Design）とは，犯罪発生の 時空間的な状況に着目し, 広い意味でのデザイン （計画・設計・整備・管理）を通して，犯行の機会 を縮滅させる諸方策をいう。技術的には，「被害

山本 俊哉* (やまもと としや) 明治大学理工学部建築学科助教授

i モラルパニックとは，現実に存在するリスク以上にリスクを感じ危機難を抱くことをいう。

ii 株富士総合研究所「生活者のセキュリティに関するアンケート調査」:ネットアンケート調査, 有効回答者数 7,488 名のう ち女性回答者数が 5,913 名。年齢は30代が最も多く，4,064名。 
対象の強化 (・回避 $) 」$ と「(犯罪企図者の) 接近 の制御」という直接的な方策と,「監視性の確保」と 「領域性の強化」という間接的な方策に分類される (図一1)。

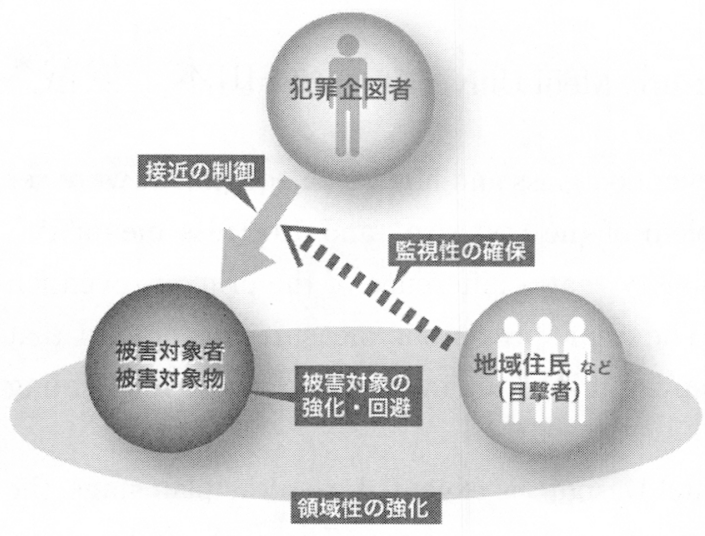

図-1防犯環境設計の基本的な方策

従来，日本においては，地域コミュニティによ るインフォーマルな社会統制と結びついた間接的 な方策を中心に犯罪予防が図られてきた。しかし， 最近は, 従来型の地域コミュニティの衰退と居住 者の自衛意識の向上があいまって，直接的な方策 に軸足が移行している。また，間接的な方策につ いても，防犯カメラの増加に象徵されるように, 人的対応よりも設備機器に依存した対応が進んで いる。

実際には，どのような防犯環境設計が進められ ているのか。犯罪予防に扔いて効果的な防犯環境 設計を進めるには，どうすべきか。

本稿では, 最近の新築住宅に関する特徴的な動 きに焦点をあて，住宅の防犯環境設計の実際的な 側面とそこに内在する課題を明らかにし，それを
通して防犯環境設計の効果的なあり方を展望する。

\section{2 「被害対象の強化」方策の実際と課題}

ここでいう住宅における「被害対象の強化（・ 回避)」方策とは, 住宅侵入盗（特に, 空き巣）を 予防するため, 主として住戸の開口部の建物部品 (錠前, ドア，空サッシ，空ガラス等）を侵入に伴 う破壊行為にある程度耐えられるように強化する ことをさす。最近の住宅の防犯環境設計の市場と 施策は, 「被害対象の強化·回避」に重点が置かれ ている。

\section{(1)防犯性能の高い建物部品の普及}

犯罪対策閣僚会議は，2005年 6 月「安全・安心 なまちづくり全国展開プラン」として当面重点的 に推進すべき施策をまとめた。この中で位置づけ られたのが防犯性能の高い建物部品（以下， CP マーク部品沼という。）の普及に関する一連の施策 である。

CPマーク部品とは, 国土交通省・経済産業省・ 警察庁と関係民間団体による「防犯性能の高い建 物部品の開発·普及に関する官民合同会議」（以下， 官民合同会議という。)の防犯性能試験に通過した 建物の開口部の部品（錠前，ドア・サッシ，ガラ ス等）をいい，2003年 4 月からその認定登録制度 が始まった。ここでいう防犯性能とは, 実際の侵 入手口に対して 5 分間耐えられる抵抗性能を指す。 警視庁が行った侵入盗の被疑者調査で，侵入行為 に 5 分以上かかると諦めると答えた者が約 7 割い たことがその根拠となっている。「(犯罪企図者の) 接近の制御」方策であるホームセキュリティの導 入も,「被害対象の強化」に効果的であるが，セン サが発報してから警備員が到着するまで（平均10 〜15分程度）に侵入口を破壞して窃盗を行う犯罪

\footnotetext{
iii「人間によってつくられる環境の適切なデザインと効率的な使用によって，犯罪に対する不安感と犯罪の減少，そして 『生活の質』の向上を導くことができる」という米国の犯罪学者のC・レイ・ジェフリィ (1971年) の考え方が国際的に 広く支持されている。

i CPとは，Crime Prevention（犯罪予防）の略。CPマーク部品は，2004年度末までに2,521品目が認定されている。
} 
企図者が少なくない。

「被害対象の強化」方策は，ユーザーや市民に とってわかりやすく，実施すればそれだけの防犯 効果が期待できることもあって, 現在, 官民双方 でC P マーク部品の普及に取り組んでいる。しか し, 2005年 4 月時点の出荷量は建物部品全体の $1 \%$ 前後にすぎないv。これは，CPマーク部品の 多くが試験段階ではまだ商品化されておらず, 2004年後半になってようやく本格的な出荷体制が 整った品目が多かったことによる。以前から出荷 していた商品の中には，CPマーク部品として認 定された防犯ガラス ${ }^{\mathrm{vi}}$ のうに, 最近出荷量が急増 している部品もある。板硝子協会によれば， 2002 年度から2004年度にかけて防犯ガラスの出荷量が 約 5 倍に拡大し, 2005 年度は前年度の 2 倍 $(200$ 万 $\mathrm{m}^{2}$ ）を超えると予想しているvii。ただし，CPマー ク部品は従来の商品と比べて価格がやや高く, そ れが住宅全体のコストアップにつながるとして二 の足を踏んでいるデベロッパーも見られる。

\section{(2)防犯に関する住宅性能表示制度の導入}

国土交通省は，2006年 3 月に住宅の品質確保の 促進等に関する法律が改正されるのに伴い, 住宅 性能表示制度に「防犯に関すること」を追加する ことを決めた。2005年 5 月に発表した案viiiによる と, 住宅（共同住宅にあっては住戸）の侵入防止 対策のため, 開口部にCPマーク部品を使用してい る場合は，その旨を表示できることとした。

住宅性能表示制度は，第三者機関が住宅性能を 評価することから，評価対象は，評価基準が整備 されており，客観評価のなじむものでなくてはな らない。そのため，国土交通省は，防犯環境設計 の 4 つの方策のうち「被害対象の強化」について
同制度案をまとめ, 他の 3 つの方策については, 評価方法の知見が蓄積された段階で評価事項の拡 大等を検討することとした。

複雑で不確実性が増している現代社会において, ユーザーはリスクに対して過敏に反応し，翻って 行政機関は安全に関する要求を強めていく傾向が ある。同制度は任意の制度であるため, 国土交通 省「防犯に配慮した共同住宅に係る設計指針」(以 下，防犯設計指針と略す。）ixと同様，何ら規制を 課すものではないが，防犯に関する評価基準案に ついては，より安全側に立った制度設計がなされ ている。その性能水準は比較的に高いが，ある八 ウスメーカーでは，すでにその評価基準案に沿っ た商品開発を進めている。おそらくそうしたハウ スメーカーがリードする形で，一戸建て住宅を中 心に，防犯に関する性能表示が進むものと思われ る。

\section{(3)「被害対象の強化」方策に内在する課題}

従来の住宅は, どちらかといえば侵入行為に対 して物理的に脆弱であったといえる。すなわち, 諸外国と比べると, 錠・扉・ガラス・面格子のい ずれも破壊行為に対して強くはなかった。国際的 な窃盗団が暗躍する今日において,「被害対象の強 化」方策は必要かつ重要な課題である。

しかしながら,「被害対象の強化」は, ある程度 の費用負担を伴う。仮に一戸建ての住宅の空全て に防犯ガラスを採用しょうとすると，かなりのコ ストアップになり，費用負担できる者とできない 者の間に防犯性能の差が生じる可能性がある。ま た，供給者側にあっては，大手ハウスメーカーの ように標準化と大量発注によってコストアップを 軽減できないと, 性能面とコスト面の両面で競争

\footnotetext{
v http://www.mlit.go.jp/kisha/kisha05/07/070407_html

vi 防犯ガラスとは，二枚の板ガラスの間に柔軟で強勒な中間膜を挟んだガラスであり，一般の板ガラスと比べるとやや高い。

vii セキュリティ産業新聞2005年 6 月 25 日

viii http://www.mlit.go.jp/pubcom/05/pubcomt31_.html

ix http://www.mlit.go.jp/jutakukentiku/house/press/h12/130323-3.htm
} 
力が低下する可能性がある。

「被害刘象の強化」の促進は, 費用負担の問題だ けでなく，安全圈に身を置く「要塞の心理」の問 題も内在している。「要塞の心理」は, 居住者の犯 罪被害の不安感を高め, 部外者に対して排他的に なり, 結果的に公共空間に対する関心が相刘的に 低下するという問題を孕んでいる。従って,「被害 対象の強化」はそれを代替または補完する方策が 必要である。

また，防犯に関する住宅性能表示制度は，全国 一律の基準であり, 制度上の制約から, 地域や敷 地の特性は考慮されていないことから, 同制度に ついても制度上の限界を補完する対策が必要であ る。

\section{3 「接近の制御」方策の実際と課題}

「(犯罪企図者の) 接近の制御」は, 一般建築で は段階的かつ重層的に警戒線（図一2）を設けて, 柵や扉, センサ等により, 利用者の出入を管理し て犯罪企図者の接近を制御する方策をいう。防犯 設計指針においては，犯罪企図者が住戸や駐車場 等の被害対象に接近しにくいように，周囲からの 見通しの確保や動線計画を工夫することも,「接近 の制御」に含めている。

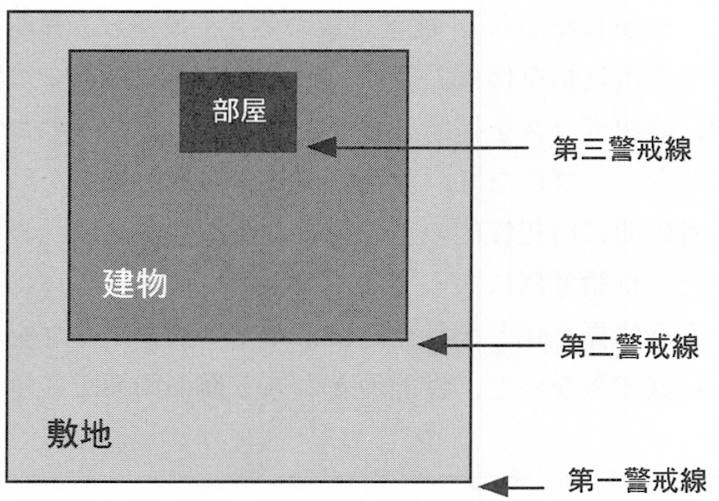

図一２警戒線の概念図

\section{(1)敷地内への接近の制御}

防犯設計指針においては，敷地内のオープンス ペースが公開空地や提供公園になっていることや 災害時の一時避難地敷地になることから, 敷地内 への接近の制御については, あまり言及していな い。しかし, 最近は, 住棟や塀・柵等で敷地内の オープンスペースを囲み，ゲートにはオートロッ クシステムを導入して部外者の利用を制限する事 例が増えている。もっとも, 駐車場は, 円滑な利 用という観点からその区画外に配置されており, 敷地境界の塀についても近隣に対する配慮から高 さが抑えられており，実際は敷地内に侵入しょう と思えば，侵入できるような造作になっている。

一戸建て住宅も同様に, 敷地内に駐車スペース を確保することもあって, 道路に対して開放的な 住宅が多く, 敷地内にセンサライト等を設置して, 心理的に接近を抑制している状況にある。

\section{(2)住棟内への接近の制御}

最近の共同住宅では, 共用立関のオートロック システムに虹彩認証や静脈認証等のバイオメトリ クス技術をを採用する事例が急速に増えている。カ ギが不要という手軽さや本人以外では解錠できな いという防犯性能が注目されているが, 事故防止 のために一般のオートロックシステムと同じょう に開いてから閉じるまで一定の時間を確保してあ り, 犯罪企図者が居住者の後を追って入ることは 可能である。こうしたこともあって，オートロッ クシステムを各階のエレベーターホール等にも採 用する事例も増えている。来訪者が住戸に入るま でに何回もインターホンで対応しなければならな いが，犯罪企図者の接近を制御する措置として受 け入れられている。

もっともオートロックシステムを導入していて も, 新聞配達やゴミ出し等のために, 共用玄関以

× 人間の持つ固有の生物学的特徽を利用した生体認証の技術。虹彩認証と静脈認証は, 認証精度が高く, 機器の小型化と低 価格化が進んでいる。 
外の共用出入口の錠を開けたままにしている共用 住宅が少なくない。一戸建ての住宅の勝手口と同 じように，周囲から見えにくい場所にあるため侵 入対策に留意しなければならない䇢所にもかかわ らず，防備が手薄になっている面が見られる。

\section{(3)隣地境界からの接近の制御}

密集市街地や幹線道路沿い等, 相互の建物が隣 地境界に近接して建っている場合は，隣接建物の 屋外階段等から直接, あるいは隣地境界の塀を足 場にして, 被害対象の住宅の空に侵入するケース が少なくない。中には，隣接建物の屋上から伝い 渡り，あるいは建設工事用の足場を利用して侵入 する例さえある。こうした場所は，人目につきに くいことから，侵入経路として選ばれやすい。と ころが，敷地内の対策に目が奪われ，そうした部 分の疎かになっている面が少なからず見られる。

\section{(4)「接近の制御」に内在する課題}

住宅における「接近の制御」方策は，住宅地， 敷地, 住棟の各エリアで様々な手だてが講じられ ている。しかし，だからといって必ずしも犯罪企 図者の接近を制御できるものにはなっていない。 通常時の利用や非常時の避難を考慮すると自ずと 限界があり，仕方がない面がある。過剩に対応す ると, 日常時の利便性や快適性を損ない, 非常時 の避難に支障が生じる可能性がある。加えて, そ の促進は,「被害対象の強化」と同様,「要塞の心 理」をもたらすおそれがある。

とはいえ，共用玄関以外の共用出入口からの侵 入防止や隣地境界からの接近の制御は,「監視性の 確保」や「被害対象の強化」, 敷地境界からセット バック等の設計の工夫によって解決できる課題で ある。人目につく部分の対策や新しい設備の活用 も重要ではあるが, 人目につきにくい部分の対策 にこそ,「接近の制御」の本質的な課題があるとい える。

\section{4 「監視性の確保」方策の実際と課題}

「監視性の確保」は，防犯性向上する上で最も基 礎的で本質的な原則として広く知られている 犯設計指針では，日常生活における自然な監視性 の確保，すなわち，周囲からの見通しの確保と一 定の照度の確保を基本とし, 防犯カメラは, 見通 しの確保の補完措置として位置づけている。

\section{(1)周囲からの見通しの確保}

犯罪企図者にとっては，実際に犯行を目撃する 人がいなくても，その可能性のある場所では目撃 されるリスクを考慮して犯行を控えるといわれて いる。そうした観点から言えば，周囲からの見通 しの確保による犯罪抑止効果は，ある程度期待で きるものである。配置計画や動線計画の工夫に よって対処できる課題であり，防犯設計指針でも それに言及しているが，必ずしも徹底されている わけではない。例えば, 開発に伴う提供公園の中 には，残余の土地にあてがったような目の届きに くい場所に配置され, 魅力に乏しく利用頻度も少 なく，結果的に人の目が少ないオープンスペース になっている場合がある。また，基本設計の段階 で周囲からの見通しの確保に充分配慮しなかった ため，やむを得ず防犯カメラを増設した例も見ら れる。

\section{(2)屋外及び共用空間における照明の確保}

防犯設計指針においては，屋内の共用空間の平 均水平面照度を50ルクスないしは20ルクス, 屋外 にあっては 3 ルクスを基本事項として示している。 都道府県の生活安全条例に基づく指針又は基準に おいてもその数值を準用しており, 新築の共同住 宅の共用空間は, 従来と比べて明るくなっている。 反面，敷地の周囲に照度の落差による暗がりが生 じているところがある。また，不適切又は過剩な 照明が，逆に視認性を低下させているケースも見

\footnotetext{
xi 参考文献 5 ）
} 
られる。

\section{(3)防犯カメラの普及}

防犯カメラは, 技術の高度化と価格の低廉化に 加え, 設置に対するニーズもあって, 新築分譲マ ンションに拈ける普及率は $90 \%$ に達し, 共用玄関, エレベーター，駐車場等の各所に設置されている。 一戸建ての住宅においても, カメラ付きインター ホンやセンサライト付きカメラ等の普及が進んで いる。

そのほとんどがビデオで録画しているが，常時 モニタリングしている住宅は少ない。監視をア ピールすることによる心理的な犯罪抑制に主眼を 置いており，ほとんどが日常時の動線上に設置さ れている。侵入経路や犯行場所になるような人目 につかない場所, 例えば, 共用玄関以外の共用入 口付近，共用階段などには，あまり見られない。

実際に設置された防犯カメラを点検すると，そ の設置場所や向きが不適切で, 撮影範囲に入って いない，あるいは逆光によるグレアxiii゙生じるな どの問題が見られる。

\section{(4)「監視性の確保」に内在する課題}

「監視性の確保」方策も, 行き過ぎると, 生活上 の様々な弊害や支障をもたらすおそれがある。例 えば，過剩な照明は，農作物の生長や安眠を妨げ， また不快感を与える等の光害を生じる場合がある。 屋外に設置された防犯カメラも, その向きによっ ては周辺民家の空が撮影対象に入り, 画像の取り 扱いによっては，プライバシーを侵害するおそれ がある。

一方，こうした問題は，設計上の工夫によって 解決することも可能である。周囲からの見通しの 確保にしても，敷地条件や構造上の制約で一定の 限界はあるものの, 設計の工夫で死角をできる限 り少なくすることは可能である。

\section{5 「領域性の強化」方策の実際と課題}

「領域性の強化」方策は, 広い意味でのデザイン を通して居住者の帰属意識や共同意識を高めるこ とをいい, 物理的な領域の明示だけでなく, 維持 管理を含めた外観の状態や戸外行動等により，心 理的に居住者の領域を知覚させることを含めてい る。「監視性の確保」と同様, 心理的に犯罪を抑止 する方策であり, また人的対応を促進させる措置 である。

(1)タウン・セキュリティ

最近, タウン・セキュリティとよばれる一戸建 ての住宅地開発が注目を集めている。日本の開発 制度は, 道路の公共移管を前提としていることか ら，諸外国のゲーテッド・コミュニティのように 住宅地の外周を塀や柵で囲い, 住宅地にアクセス する道路にゲートに設置した住宅地は見られない。 日本にも住宅地の外周を水路や個々の住宅の塀を 連続させて区画し, 外部からその住宅地にアクセ スする箇所を限定している事例は見られるが, 諸 外国のように部外者の通行を妨げているわけでは ない。多くは, 新規開発に伴い一括して警備会社 と契約し，警備員による巡回パトロールサービス やホームセキュリティサービスを導入し，また街 路や公園等にウエブカメラを設置し, その画像を 居住者がパソコン上で監視できるようにして，犯 罪予防を図っている。

\section{(2)共有する住戸数の制限}

共用空間を共有する住戸数が多くなると, 領域 性が低下するとして，欧米諸国では，共有する戸 数を10戸程度に抑える方策がとられている。また， 共用廊下における柵の設置等によって区画してい る改修事例も見られる。

一方，日本においては，防犯設計指針でも住戸 数についてはあまり言及していないし, 実際に供

xii 光源による画像の見えにくさのことをいう。 
給された共同住宅においても, 防犯上の理由で共 有する住戸数を制限した事例はほとんど見られな い。

\section{(3)コミュニティ形成の促進}

最近の超高層や大規模な共同住宅を見ると，そ のスケールメリットを活かして, キッズルームや フィットネスルーム, パーティルーム等の多種多 様な共用施設が用意されているものが目につく。 居住者相互のコミュニケーションの機会の創出に は役立っているとは思われるが，それが共同意識 の向上にどの程度役立っているかどうか定かでは ない。

\section{(4)「領域性の強化」方策に内在する課題}

「領域性の強化」方策も, 行き過ぎると, 部外者 に対して排他的になるおそれがあるが，本質的に は居住者の特性や住宅の所有関係が大きく影響す ることため, 一概にそうとはいえない。また，実 際に問題が顕在化しているわけではない。むしろ, 「領域性の強化」方策を物理的に区画する方策とし て短絡的に理解する傾向こそ問題であるといえる。

\section{6 おわりに：防犯環境設計の効果的なあり方}

本稿では, (1)犯罪子防のニーズを反映し, 防犯性能 の高い建物部品やハイテク設備の活用が顕著に進 んでいること, (2)こうした方策は費用負担や「要 塞の心理」の問題を内在しており, バランスに留 意しないと防犯性能の格差や生活上の様々な支障 が生じる可能性があること, (3)よく目につく部分 の防犯対策は進んでいるが, 人目につきにくい部 分の防犯対策が疎かになっており, 照明設備や防 犯カメラの設置に不適切な措置が見られることな どを指摘した。
もとより，防犯環境設計は, 犯罪子防の一方策 にすぎず，自ずと限界がある。従って，それを代 替又は補完する方策xiiiを用意し, それらを併用し て犯罪予防に取り組む必要がある。

とはいえ, 防犯環境設計は, 配置計画や動線計 画の段階から取り組めば, 効果的でバランスのと れた対策を講じることができるし，防犯性能の高 い建物部品やハイテク設備の活用とそれに伴うコ ストアップを最小限にとどめることも可能である。 また，人的対応と組み合わせることによって，居 住者やコミュニティのエンパワーメントxivや住環 境のアメニティを高める可能性も秘めている。

最近の動きは, 客観的に評価できる対策や分か りやすい対策に目が奪われがちであるが，あくま でも防犯環境設計は, 地域や住宅の特性に応じて 包括的に取り組むことが基本であり，今後はそう した即地的な取組みを支援する技術的・社会的な システムを充実していくことが必要であると思わ れる。

\section{(参考文献)}

1) 山本俊哉「防犯まちづくり 子ども・住まい・地 域を守る」ぎょうせい，2005年

2 ) 山本俊哉「防犯まちづくりにおける公共施設等の 整備・管理に係る留意事項の特徵」日本建築学会 技術報告集第21号，2005年

3 ) 竹井隆人「集合住宅デモクラシー」世界思想社, 2005年

4) 都市住宅学会「特集: 住宅地の犯罪防止 〜住まい を開くこと,閉じること」都市住宅学第48号, 2005 年

5 ） (財)ベターリビング, (財住宅リフォーム・紛争処理 支援センター「共同住宅の防犯設計ハンドブッ ク」創樹社, 2001年

\footnotetext{
xiii 例えば，居住者や周辺住民による防犯パトロール活動等。英米では，防犯環境設計は，市民防犯活動，地域警察活動とと もに「コミュニティ防犯」のひとつとして位置づけている。

xiv WHOのオタワ憲章ではエンパワーメントを「自分たちの生活への統御を獲得する過程」と定義づけている。
} 